\title{
Did the loss of phytoplanktivorous fish contribute to algal blooms in the Mwanza Gulf of Lake Victoria?
}

\author{
F. Witte - G. M. Silsbe $\cdot$ R. E. Hecky $\cdot$ \\ P. C. Goudswaard $\cdot$ S. J. Guildford $\cdot$ \\ M. A. Kishe-Machumu • J. H. Wanink
}

Received: 5 January 2011 /Revised: 8 September 2011/ Accepted: 11 September 2011 / Published online: 28 September 2011

(C) The Author(s) 2011. This article is published with open access at Springerlink.com

\begin{abstract}
Possible causes of the increased algal blooms in Lake Victoria in the 1980s have been disputed by several authors; some suggested a topdown effect by the introduced Nile perch, whereas others suggested a bottom-up effect due to eutrophication. In this article the potential impact is established of grazing by fish on phytoplankton densities, before the Nile perch upsurge and the concomitant algal blooms in the Mwanza Gulf. The biomass and trophic composition of fish in the sublittoral area of the Mwanza Gulf were calculated based on catch data from bottom trawls, and from gill nets covering the whole water column. Estimates of phytoplankton
\end{abstract}

Handling editor: I.A. Nagelkerken

F. Witte $(\bowtie) \cdot$ P. C. Goudswaard .

M. A. Kishe-Machumu - J. H. Wanink

Institute of Biology Leiden, University of Leiden,

P.O. Box 9505, 2300 RA Leiden, The Netherlands

e-mail: F.Witte@biology.leidenuniv.nl

F. Witte

Netherlands Centre for Biodiversity, Naturalis, P.O. Box 9517, 2300 RA Leiden, The Netherlands

\section{G. M. Silsbe}

Netherlands Institute of Ecology, Centre for Marine and Estuarine Research (NIOO-CEME), P.O. Box 140, 4400

AC Yerseke, The Netherlands

R. E. Hecky · S. J. Guildford

Large Lakes Observatory, University of Minnesota,

2205 E. 5th Street, Duluth, MN 55812, USA production in the same area were made from Secchi values and chlorophyll concentrations. The total phytoplankton intake by fish was estimated at $230 \mathrm{mg} \mathrm{DW} \mathrm{m}{ }^{-2}$ day $^{-1}$. The daily gross production ranged from 6,200 to $7,100 \mathrm{mg} \mathrm{DW} \mathrm{m}^{-2} \mathrm{day}^{-1}$ and the net production from 1,900 to $2,200 \mathrm{mg}$ DW m ${ }^{-2}$ day $^{-1}$. Thus, losses of phytoplankton through grazing by fish were about $3-4 \%$ of daily gross and $10-12 \%$ of daily net phytoplankton production. As a consequence it is unlikely that the phytoplankton blooms in the second half of the 1980s were due to a top-down effect caused by a strong decline in phytoplankton grazing by fish.

P. C. Goudswaard

Institute for Marine Resources and Ecosystem Studies (IMARES), Wageningen UR, P.O. Box 77, 4400 AB Yerseke, The Netherlands

M. A. Kishe-Machumu

Tanzania Fisheries Research Institute (TAFIRI), P.O. Box

78850, Dar es Salaam, Tanzania

J. H. Wanink

Koeman en Bijkerk bv, Ecological Research and

Consultancy, P.O. Box 111, 9750 AC Haren,

The Netherlands 
Keywords Bottom-up effect - Haplochromine cichlids · Phytoplankton grazing · Phytoplankton production - Top-down effect - Water transparency

\section{Introduction}

Due to human activities, eutrophication of Lake Victoria has been increasing since the 1920s (Hecky, 1993; Hecky et al., 1994, 2010; Scheren et al., 2000; Lung'ayia et al., 2001; Verschuren et al., 2002). Since the 1980s, algal blooms and shifts towards cyanobacteria dominance have been observed (Ochumba \& Kibaara, 1989; Hecky, 1993; Mugidde, 1993; Verschuren et al., 2002). Decomposition of algae that had sunk to the bottom contributed to a serious decrease in dissolved oxygen concentrations (Ochumba \& Kibaara, 1989; Hecky et al., 1994).

In the Mwanza Gulf, increased algal blooms and decreased water transparency and oxygen concentrations were observed concomitantly with the upsurge of the introduced predator Nile perch Lates niloticus (L.) (Wanink et al., 2001; Witte et al., 2005). Between 1983 and 1987, Nile perch increased in abundance until it contributed more than $90 \%$ to the demersal fish catches in the sublittoral and offshore waters. Simultaneously, the haplochromine cichlids, which used to make up more than $80 \%$ of the catches, almost vanished and the trophic diversity of the fish fauna decreased strongly (Witte et al., 1992, 2007a, b; Goudswaard et al., 2008). By 1987 the phytoplanktivorous and detritivorous cichlids that previously dominated the ichthyomass in sublittoral areas had disappeared almost completely (Witte et al., 1992, 2007b). A considerable part of the diet of these two trophic groups consisted of phytoplankton, especially diatoms and cyanobacteria (Goldschmidt et al., 1993; Kishe-Machumu et al., 2008). In the diet of the phytoplanktivores, cyanobacteria dominated. They were shown to be digestible by tilapiine and haplochromine cichlids at stomach $\mathrm{pH}$ values below 2.0 (Moriarty et al., 1973).

Between 1988 and 2005 some detritivorous species showed a slow recovery, but the number of individuals was low compared to those in the past (Witte et al., 2007a, b). Moreover, the resurging species did not feed on phytoplankton anymore (Kishe-Machumu et al., 2008).
The ecological changes in Lake Victoria triggered debates about their potential causes, including the roles of bottom-up and top-down effects (Kilham \& Kilham, 1990; Ogutu-Ohwayo \& Hecky, 1991; Hecky \& Bugenyi, 1992; Goldschmidt et al., 1993; Ochumba, 1995, Kolding et al., 2008; Hecky et al., 2010). Topdown effects (e.g. Goldschmidt et al., 1993) would invoke the eradication of phytoplanktivorous fish by overfishing and Nile perch predation as the primary cause of the increase in algal blooms; whereas, bottom-up effects would be expected from documented increases in nutrient concentrations in Lake Victoria (e.g. Hecky et al., 2010). However, thus far no attempt has been made to quantify the original biomass of phytoplanktivorous fish and their potential impact on phytoplankton densities. In this study we determined the biomass and trophic composition of the major fish taxa in the entire column of the sublittoral (6-20 m deep) waters of the Mwanza Gulf in 1979-1982, just before most of the phytoplanktivorous fish started to disappear. Next, we estimated the daily intake of phytoplankton by fish in the area, using these biomass data and data on ingestion rates of related cichlid species from Lake George (Moriarty et al., 1973).

Water transparency, photosynthetic rates and chlorophyll $a$ biomass strongly co-vary in Lake Victoria (Silsbe, 2004; Silsbe et al., 2006) and empirical relationships based on these co-variations allow accurate estimates of phytoplankton production from historical water transparency data and historical chlorophyll data. By comparing the historical data on phytoplankton production and phytoplankton grazing by fish, we tried to establish the potential impact of the change in phytoplanktivorous fish on the algal biomass in the Mwanza Gulf.

\section{Materials and methods}

\section{Fish biomass}

Benthic trawl catches and gill net catches covering the entire water column were used to estimate biomass and trophic composition of the fish stocks in the sublittoral areas of the Mwanza Gulf before the ecological changes. Bottom trawl catches by MV Mdiria (120 hp, head rope $25 \mathrm{~m}$, cod end mesh $20 \mathrm{~mm}$ ) recovered 30 hauls of $45 \mathrm{~min}$ duration during 


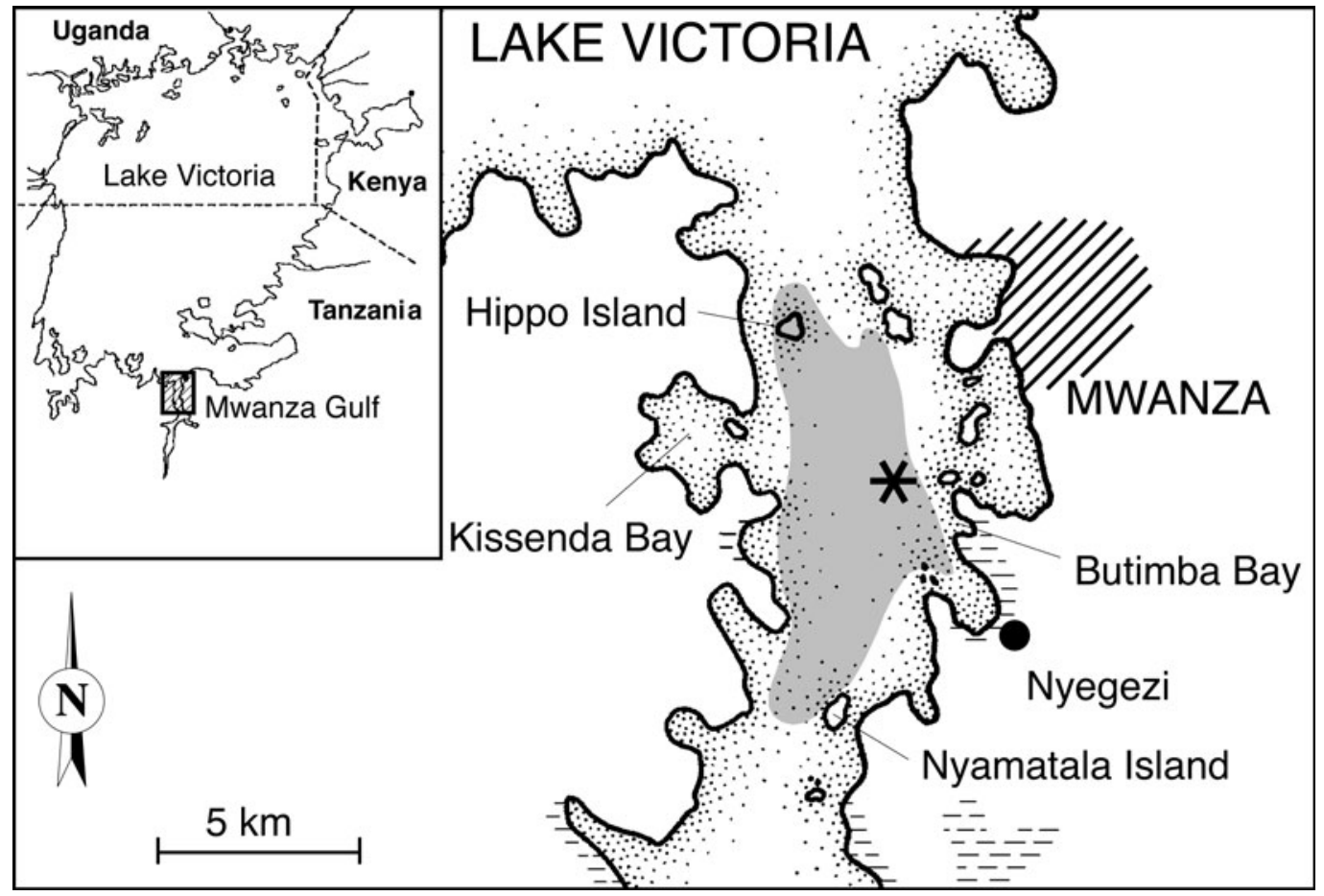

Fig. 1 Map of the study area in the northern part of the Mwanza Gulf. Shaded area was fished with bottom trawls from January 1978 to February 1979. Asterisk indicates station G where gill nets were set between August 1981 and July 1982

daytime between January 1978 and February 1979 in the northern part of the Mwanza Gulf (depth range 6-18 m; Fig. 1).

From the head rope length of $25 \mathrm{~m}$ and the estimated speed of 3.5 nautical miles per hour (1 nautical mile = $1,852 \mathrm{~m}$ ) of MV Mdiria, the swept area was calculated as:

$$
\begin{aligned}
& (25 \times 0.33) \times(3.5 \times 1,852)=53476.5 \mathrm{~m}^{2} \mathrm{~h}^{-1} \\
& \quad=5.35 \mathrm{hah}^{-1}
\end{aligned}
$$

The correction factor 0.33 for the net opening is based on estimates that have been made for the gear of MV Kiboko in the same area (W. van der Hak, pers. comm.). Due to the soft mud bottom in the Mwanza Gulf, the effective net opening of bottom trawls is considerably smaller than on more firm bottoms.

The trophic composition of the catches was estimated by splitting up the haplochromine and other fish species according to the main components in their diet (e.g. Corbet, 1961; Witte \& van Oijen, 1990). Samples of 2-2.5 kg haplochromine cichlids, containing 400-600 individuals, were sorted to species and trophic level to estimate biomass of different trophic groups of haplochromine cichlids. The mean weight of individuals in each trophic group was calculated from 15 samples from bottom trawl catches. From these mean weights correction factors were calculated that were used to convert percentage trophic composition based on numbers, to percentage composition based on weight. The biomasses of the demersal, non-haplochromine trophic groups were derived from the same trawl catches.

To estimate biomass and community composition of fish in the water column, gill net catches were made during 8 days and 8 nights between 17 August 1981 and 18 July 1982 at the $13-15 \mathrm{~m}$ deep station $\mathrm{G}$ (Fig. 1). The gill nets consisted of a bottom, mid-water and top set net. Each net was $60 \mathrm{~m}$ long and $1.5 \mathrm{~m}$ deep, and composed of six panels of $10 \mathrm{~m}$, with mesh sizes of $2.5 \mathrm{~cm}\left(1^{\prime \prime}\right), 3.8 \mathrm{~cm}\left(1.5^{\prime \prime}\right), 5.1 \mathrm{~cm}\left(2^{\prime \prime}\right)$, $2.5 \mathrm{~cm}$, etc. In addition, a vertical gill net covering the entire water column was used. This net had a height of $15 \mathrm{~m}$, a width of $5 \mathrm{~m}$ and a mesh size of $2.5 \mathrm{~cm}$ (Goudswaard et al., 1995). Gill nets were set from 10.00 to $16.00 \mathrm{~h}$ during the day and from 22.00 to $04.00 \mathrm{~h}$ at night. 
We calculated the trophic composition in both vertical and normal gill nets from the numbers of haplochromine cichlids in the catches per 24-h session. The catch ability per trophic group differed depending on gill net type and time of the day. Vertical nets had higher catches at night than by day. The reverse was observed in the conventional gill nets. Therefore, both the horizontal and vertical gill net catches from day and night were used to calculate the mean percentage composition of the haplochromine trophic groups in the entire column. As in the bottom trawls, this was converted to percentage weight composition, using the above mentioned correction factors.

\section{Phytoplankton consumption}

To estimate phytoplankton consumption we used the formulae of Moriarty et al. (1973), who calculated ingestion rates based on diurnal changes in dry weight of stomach and intestine contents, for the two main phytoplanktivorous fish species of Lake George: H. (Enterochromis) nigripinnis Regan and Oreochromis niloticus (L.).

The quantities of phytoplankton were linearly related to the weight of the fish:

$$
\begin{gathered}
y=-29.6+21.9 x, \quad \text { for H.nigripinnis } \\
y=271+13.3 x, \quad \text { for O.niloticus }
\end{gathered}
$$

where $y$ is the dry weight (DW) of the phytoplankton ingested in mg per day and $x$ is the wet weight of fish in grams. These equations were derived from studies with $H$. nigripinnis in the size range of $5-8 \mathrm{~cm}$ total length (TL) and $O$. niloticus of 15-23 cm TL. Since much of the biomass of both species in the lake was made up of individuals within the size ranges studied, the grazing rate per population was established as:

$$
\begin{gathered}
I=-n 29.6+21.9 B, \text { for H.nigripinnis of } 5-8 \mathrm{~cm} \mathrm{TL} \\
I=n 271+13.3 B, \quad \text { for O.niloticus of } 15-23 \mathrm{~cm} \mathrm{TL}
\end{gathered}
$$

in which $I$ is ingestion in mg DW per day in the area occupied, $n$ is number of fish and $B$ is their biomass in grams fresh weight. The detritivorous and phytoplanktivorous haplochromines from Lake Victoria are similar to H. nigripinnis in both size and shape. According to Kudhongania \& Cordone (1974b), the Oreochromis catches in the 1970s in the Mwanza Gulf were a mixture of O. esculentus (Graham), O. variabilis (Boulenger) and $O$. niloticus. Their mean lengths were ranging from 24 to $30 \mathrm{~cm}$ TL (Goudswaard et al., 2002), which was larger than in Lake George. When calculating the ingestion rate we took into consideration that in most species phytoplankton was only a part of the diet by multiplying $I$ with the fraction of phytoplankton in the diet.

Phytoplankton production and biomass

In the absence of direct measurements of gross and net phytoplankton production (NPP) in the late 1970s, these parameters were estimated using historical water transparency records in the study area, measured between April 1973 and January 1975 (Akiyama et al., 1977; Toshio Akiyama, unpublished report Freshwater Fisheries Institute Nyegezi, Mwanza), and in 1979 (van Oijen et al., 1981). Using both historical and current limnological datasets on Lake Victoria, Silsbe et al. (2006) demonstrated that water transparency $($ Secchi Depth $=\mathrm{SD})$ is highly correlated $\left(r^{2}=0.78\right)$ with phytoplankton chlorophyll concentrations, that in turn are significantly correlated with gross phytoplankton production (GPP) $\left(r^{2}=0.83\right)$. From these data an empirical model estimated chlorophyll concentrations from water transparency measurements and then converted these into estimates of daily GPP at different sites in the study area (Fig. 2; Silsbe, 2004). GPP is converted into units of carbon by multiplying by the ratio of molar weight of carbon to oxygen (12/32) and dividing by a nominal photosynthetic quotient of 1.2.

$$
\begin{aligned}
& \mathrm{Chl}\left(\mathrm{mg} \mathrm{Chl} \mathrm{m}^{-3}\right)=35.9 \times\left[\mathrm{SD}^{-1}\right]^{1.66} \\
& \operatorname{GPP}\left(\mathrm{g} \mathrm{O}_{2} \mathrm{~m}^{-2} \mathrm{day}^{-1}\right)=11.3 \times \tanh (0.2 \times \mathrm{Chl}) \\
& \operatorname{GPP}\left(\mathrm{g} \mathrm{C} \mathrm{m}^{-2} \text { day }^{-1}\right)=\mathrm{GPP} \times 12 / 32{\mathrm{~g} \mathrm{C} / \mathrm{g} \mathrm{O}_{2}} \times(1 / 1.2)
\end{aligned}
$$

The majority of GPP is lost directly through phytoplankton respiration. NPP is the amount of GPP not respired and therefore available to grazers. NPP is estimated here based on previous measurements of the ratio of NPP:GPP in Lake Victoria. Limited direct measurements of GPP and NPP in Mwanza Gulf in 1972 and 1973 showed that NPP was between 81 and 93\% of GPP ( $n=2$, Søren Olsen, unpublished report, Freshwater Fisheries Institute, Mwanza), while modern day measurements in three nearshore embayments 

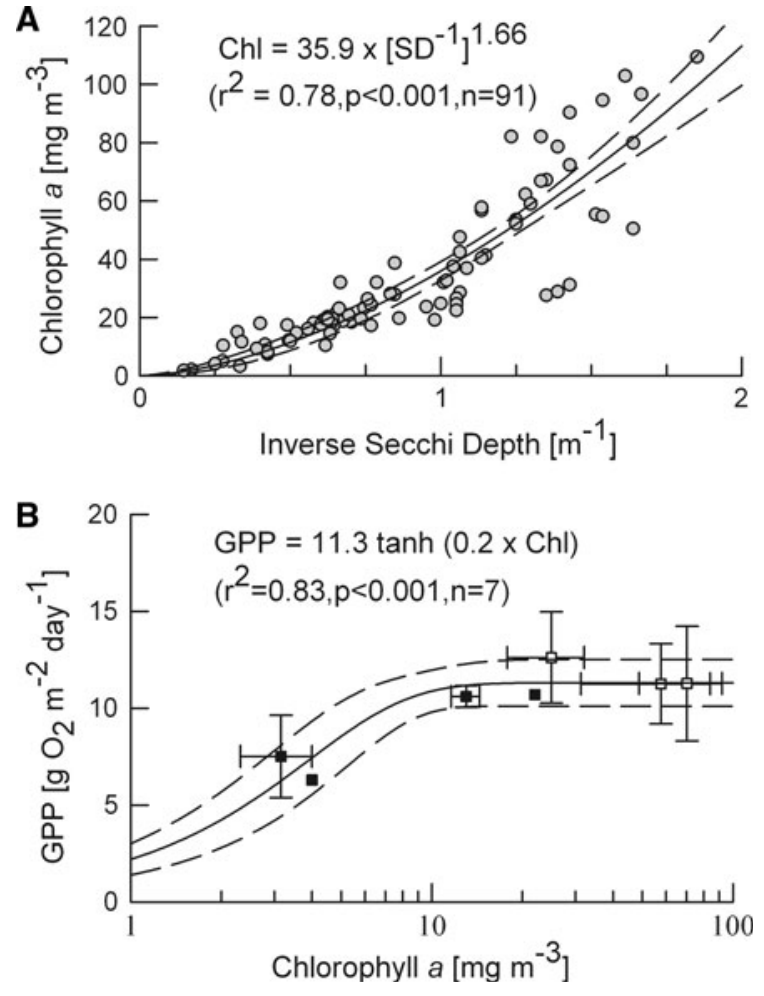

Fig. 2 Regression of $\mathbf{A}$ the inverse Secchi depth versus chlorophyll $\alpha$ and $\mathbf{B}$ chlorophyll $\alpha$ versus areal GPP. Solid and dashed lines in both panels indicate model fits and their 95\% confidence intervals, respectively. For (B) data points and error bars, where present, represent the means and standard deviations of multiple measurements within a geographic area. Filled and open squares are from Talling (1965) and Silsbe et al. (2006), respectively

in Lake Victoria showed that an average NPP was $31 \%$ of GPP ( $n=22$, Silsbe 2004). To convert GPP to NPP we used the more conservative $31 \%$ to yield smaller values of NPP available to grazing. To convert NPP into phytoplankton DW, we multiplied NPP by a factor of 2 to convert $\mathrm{mg}$ of $\mathrm{C}$ to $\mathrm{mg}$ of $\mathrm{DW}$.

$$
\begin{aligned}
& \text { NPP }\left(\mathrm{mg} \mathrm{DW} \mathrm{m}^{-2} \mathrm{day}^{-1}\right)=\mathrm{GPP} \times 0.31 \\
& (\mathrm{GPP}: \mathrm{NPP}) \times 1,000 \mathrm{mg} \mathrm{C} / \mathrm{g} \mathrm{C} \\
& \times 2 \mathrm{mg} \mathrm{DW} / \mathrm{mg} \mathrm{C}
\end{aligned}
$$

As an alternative approach to estimate biomass of phytoplankton for comparison with fish ingestion of phytoplankton we used the chlorophyll concentrations as derived from SD measurements above, multiplied these measurements by $8 \mathrm{~m}$ to derive the areal concentration for the $8 \mathrm{~m}$ deep station at the southern border of our study area, multiplied this value by an assumed carbon to chlorophyll weight ratio of 72 (Guildford et al., 2003) for nutrient replete phytoplankton, then multiplied this by a factor of 2 to convert $\mathrm{mg}$ of $\mathrm{C}$ to $\mathrm{mg}$ of $\mathrm{DW}$.

$$
\begin{aligned}
\mathrm{DW}\left(\mathrm{mg} \mathrm{m}^{-2}\right)= & \mathrm{Chl}\left(\mathrm{mg} \mathrm{m}^{-3}\right) \times 8 \mathrm{~m} \\
& \times 72 \mathrm{mg} \mathrm{C} / \mathrm{mg} \mathrm{Chl} \\
& \times 2 \mathrm{mg} \mathrm{DW} / \mathrm{mg} \mathrm{C}
\end{aligned}
$$

\section{Results}

Fish biomass

\section{Demersal fish from bottom trawls}

The mean catch rate of haplochromines with MV Mdiria during 1978/1979 was $1,138 \mathrm{~kg} \mathrm{~h}^{-1}$. Detritivores made up more than $60 \%$ of the total number of fish in these catches, zooplanktivores ca. 30\%, insectivores $3 \%$ and the other groups each less than $1 \%$ (Table 1). Individuals of species belonging to detritivores, phytoplanktivores and zooplanktivores, had a mean weight between 5 and $6 \mathrm{~g}$ (mean TL of the species ranged from 7 to $8.5 \mathrm{~cm}$ ). Mean individual weight of the prawn eaters was approximately twice as high as that of detritivores and planktivores; that of insectivores (of the Empodisma group, Hoogerhoud \& Witte, 1981), molluscivores and piscivores about three and a half times as high as that of detritivores and planktivores. After correction for their heavier individual weight the contributions to the catch of molluscivores and piscivores increased to approximately 2 and 3\%, respectively, and for insectivores to almost 10\% (Table 1). Zooplanktivores and detritivores made up, respectively, ca. 27 and 55\% of the catch weight. From these weight percentages and the mean catch rate for all haplochromines together $\left(1,138 \mathrm{~kg} \mathrm{~h}^{-1}\right)$, the catch rate per hour and the demersal biomass $\mathrm{ha}^{-1}$ per trophic group were calculated. The total demersal biomass of haplochromines was $212.8 \mathrm{~kg} \mathrm{ha}^{-1}$ of which $116.1 \mathrm{~kg} \mathrm{ha}^{-1}$ was contributed by the detritivores and only $0.4 \mathrm{~kg} \mathrm{ha}^{-1}$ by the phytoplanktivores (Table 1). The non-haplochromines, consisting of the piscivorous Lates niloticus, Bagrus docmak Forsskål and Clarias gariepinus (Burchell), the molluscivorous Protopterus aethiopicus Heckel, and the phytoplanktivorous tilapiine cichlids (Oreochromis spp.), together contributed $15.7 \mathrm{~kg} \mathrm{ha}^{-1}$ to the demersal fish stocks, of which the latter 
Table 1 Haplochromine composition in bottom trawls in the sublittoral area of the Mwanza Gulf in 1978/1979

\begin{tabular}{lrlrr}
\hline & $\% \mathrm{nr}$ & corr. & $\% \mathrm{wt}$ & $\mathrm{kg} \mathrm{ha}^{-1}$ \\
\hline Haplochromines & & & & \\
Detritivores & 61.3 & 1 & 54.5 & 116.1 \\
Phytoplanktivores & 0.2 & 1 & 0.2 & 0.4 \\
Zooplanktivores & 30.4 & 1 & 27.1 & 57.6 \\
Insectivores & 3.1 & 3.5 & 9.7 & 20.6 \\
Molluscivores & 0.7 & 3.5 & 2.2 & 4.6 \\
Piscivores & 0.9 & 3.5 & 2.8 & 6.0 \\
Prawn eaters & 0.1 & 2 & 0.2 & 0.4 \\
Rest & 3.8 & 1 & 3.4 & 7.2 \\
Total & & & & 212.8 \\
Non-haplochromines & & & & \\
Phytoplanktivores & & & & 1.9 \\
Molluscivores & & & & 7.2 \\
Piscivores & & & & 6.6 \\
Total & & & & 15.7 \\
\hline
\end{tabular}

The percentage of the number ( $\% \mathrm{nr}$ ) of fishes in the catch was transformed into percentage of weight $(\% \mathrm{wt})$ by a correction factor (corr.) for weight per trophic group. From the percentage of weight, the catch rate per hour and the swept area $\left(53476.5 \mathrm{~m}^{2}=5.35 \mathrm{ha} \mathrm{h}^{-1}\right)$, the biomass per hectare $\left(\mathrm{kg} \mathrm{ha}^{-1}\right)$ was calculated. The non-haplochromines comprise the phytoplanktivorous Oreochromis spp., the molluscivorous Protopterus aethiopicus and the piscivorous Lates niloticus, Bagrus docmak and Clarias gariepinus

phytoplanktivorous group made up only $1.9 \mathrm{~kg} \mathrm{ha}^{-1}$. The total demersal fish biomass amounted to: $212.8 \mathrm{~kg} \mathrm{ha}^{-1}+15.7 \mathrm{~kg} \mathrm{ha}^{-1}=228.5 \mathrm{~kg} \mathrm{ha}^{-1}$.

\section{Demersal and pelagic fish from gill nets}

Compared to the bottom trawl catches, which were estimated to cover only the bottom $2 \mathrm{~m}$ of the water column, the gill net catches over the total column revealed a relatively large group of phytoplanktivorous haplochromines (almost 18\% of weight in the gill net catches compared to $0.2 \%$ in bottom trawl catches; Tables 1 and 2). These fish were living near the surface (Fig. 3) and, consequently, were rarely caught in bottom trawls. A considerable part of the zooplanktivores also occurred in the column outside the range of bottom trawls (Fig. 3).

The bottom dwelling detritivores, which dominated the trawl catches by day, were used to calculate the biomass of the haplochromine trophic groups in the entire column. From the vertical distribution in the gill net catches (Fig. 3), it was estimated that, during daytime, bottom trawls (up to $2 \mathrm{~m}$ above bottom) caught approximately two-third of the detritivores in the area covered. Therefore, the total biomass of this group was estimated at:

$3 / 2 \times 116.1 \mathrm{~kg} \mathrm{ha}^{-1}=174.2 \mathrm{~kg} \mathrm{ha}^{-1}$

The fraction of detritivorous haplochromines in the whole column (based on gill net catches) comprised $31.1 \%$ of the total haplochromine biomass in our study area (Table 2). From the fractions of the other trophic groups we calculated the biomass as well as the total standing stock of the haplochromines $\left(560 \mathrm{~kg} \mathrm{ha}^{-1}\right)$.

The contribution of the small, pelagic, zooplanktivorous cyprinid Rastrineobola argentea (Pellegrin) has been estimated by Wanink et al. (2005) at $5.2 \mathrm{~kg} \mathrm{ha}^{-1}$ from catches with floating trawls; these fish were too small to be caught in our gill nets. By adding the biomass of the non-haplochromines, the total fish biomass in the Mwanza Gulf was established at $581 \mathrm{~kg} \mathrm{ha}^{-1}$ prior to the Nile perch upsurge (Table 2). Phytoplanktivores contributed $102 \mathrm{~kg} \mathrm{ha}^{-1}$ and detritivores, which also included phytoplankton in their diet, $174 \mathrm{~kg} \mathrm{ha}^{-1}$ (Table 2).

\section{Phytoplankton consumption}

The diet of the phytoplanktivore $H$. (?) bwathondii Niemantsverdriet \& Witte was made up of about $90 \%$ phytoplankton (the cyanobacteria Microcystis and Anabaena and the diatom Aulacoseira = Meloisira; Goldschmidt et al., 1993). The same percentage was used for the Oreochromis species, which are reported to feed predominantly on phytoplankton, either from the column or after sedimentation (Lowe-McConnell, 1956; Welcomme, 1967; Trewavas, 1983).

The detritivores in bottom trawls consisted for $37 \%$ of $H$. (Enterochromis) coprologus Niemantsverdriet \& Witte and for $63 \%$ of so called curved heads; a group of closely related species including $H$. (E.) cinctus Greenwood \& Gee, H. (E). antleter Mietes \& Witte and $H$. (E.) katunzii ter Huurne \& Witte (de Zeeuw et al., 2010). The respective diets of $H$. coprologus and the curved heads contained about 25 and $10 \%$ phytoplankton, mainly Aulacoseira (Goldschmidt et al., 1993). The most common zooplanktivore $H$. (Yssichromis) heusinkveldi Witte \& Witte-Maas, 
Table 2 Total fish biomass in the sublittoral area of the Mwanza Gulf calculated from the trophic composition in the total column in $1981 / 1982$ and the demersal biomass derived from bottom trawl catches in 1978/1979 (see text)

\begin{tabular}{|c|c|c|c|c|c|}
\hline Group & $\begin{array}{l}\text { Haplochromines } \\
\text { (\% nr in column })\end{array}$ & $\begin{array}{l}\text { Haplochr. } \\
\text { (\% weight) }\end{array}$ & $\begin{array}{l}\text { Haplochr. } \\
\left(\mathrm{kg} \mathrm{ha}^{-1}\right)\end{array}$ & $\begin{array}{l}\text { Other taxa } \\
\left(\mathrm{kg} \mathrm{ha}^{-1}\right)\end{array}$ & $\begin{array}{l}\text { Total } \\
\left(\mathrm{kg} \mathrm{ha}^{-1}\right)\end{array}$ \\
\hline Detr & 37.7 & 31.3 & 174.2 & & 174.2 \\
\hline Phyt & 21.5 & 17.7 & 99.9 & 1.9 & 101.8 \\
\hline Zoop & 30.1 & 24.8 & 138.7 & $5.2^{*}$ & 143.9 \\
\hline Insect & 5.1 & 14.7 & 82.5 & & 82.5 \\
\hline Moll & 0.9 & 2.6 & 14.6 & 7.2 & 21.8 \\
\hline Pisc & 1.9 & 5.5 & 30.7 & 6.6 & 37.3 \\
\hline Prawn & 1.3 & 2.1 & 12.0 & & 12.0 \\
\hline Rest & 1.6 & 1.3 & 7.4 & & 7.4 \\
\hline Total & & & 560.0 & 20.9 & 580.9 \\
\hline
\end{tabular}

* The biomass of the pelagic zooplanktivore Rastrineobola argentea is based on data from Wanink et al. (2005)

which made up $46 \%$ of the zooplanktivores in the bottom trawls, had a considerable amount (20-40\%) of cyanobacteria in its diet (Goldschmidt et al., 1990). Therefore, we also included it in our calculations.

From the mean weight per individual and the biomass per $\mathrm{m}^{2}(B)$, the number $(n)$ of individuals per $\mathrm{m}^{2}$ was calculated for the above mentioned fish species (Table 3). With the formulae of Moriarty et al. (1973; see Materials and methods) and the proportions of phytoplankton in the diet we calculated the ingestion rate per species. This was highest $(151 \mathrm{mg} \mathrm{DW}$ $\mathrm{m}^{-2}$ day $^{-1}$ ) in the phytoplanktivorous $H$. bwathondii, both due to its high biomass in the study area and the high proportion of phytoplankton in its diet. Though a similar proportion was estimated for Oreochromis spp., their total ingestion rate was lowest $(2.4 \mathrm{mg}$ $\mathrm{DW} \mathrm{m}^{-2}$ day $^{-1}$ ) due to their relatively low biomass in the study area. The ingestion rate of the other species ranged from 18 to $32 \mathrm{mg} \mathrm{DW} \mathrm{m}^{-2}$ day $^{-1}$. The total ingestion rate of phytoplankton by all species together is estimated at $230.7 \mathrm{mg} \mathrm{DW} \mathrm{m}^{-2}$ day $^{-1}$ (Table 3).

\section{Phytoplankton production}

Monthly Secchi measurements taken in the Mwanza Gulf between April 1973 and January 1975 at the southern border of the research area $(<2 \mathrm{~km}$ south of Nyamatala Island, $8 \mathrm{~m}$ deep), ranged from 1.1 to $1.9 \mathrm{~m}$ (Akiyama et al., 1977). Measurements more towards the centre of the research area (close to station G) from March 1974 to January 1975 ranged from 1.3 to $2.5 \mathrm{~m}$ (Toshio Akiyama, unpublished report). In the period February to April 1980 we measured Secchi values of $2.1-2.7 \mathrm{~m}$ at station $\mathrm{G}$.

Using the empirically derived model (Fig. 2A; Silsbe, 2004), we first estimated that chlorophyll concentrations likely ranged from 6.9 to $30.6 \mathrm{mg}$

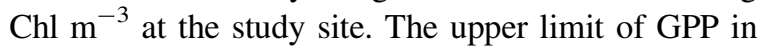
Lake Victoria predicted by the empirical model (Fig. 2B) occurs near $11 \mathrm{mg} \mathrm{Chl} \mathrm{m}^{-3}$. As chlorophyll concentrations increase beyond $11 \mathrm{mg} \mathrm{m}^{-3}$, GPP is constrained within increasingly shallower euphotic depths with diminished photosynthetic rates (Silsbe et al., 2006). Consequently, despite the large range in estimated chlorophyll concentrations, we estimated a truncated range of GPP between 10 and $11.3 \mathrm{~g} \mathrm{O}_{2} \mathrm{~m}^{-2}$ $\mathrm{day}^{-1}$. Converting this data into carbon units yields GPP estimated between 3.1 and $3.5 \mathrm{~g} \mathrm{C} \mathrm{m}^{-2}$ day $^{-1}$, remarkably close to the mean value of unpublished data measured by Søren Olsen near the study site in 1972 and $1973\left(n=2,3.0 \mathrm{~g} \mathrm{C} \mathrm{m}^{-2} \mathrm{day}^{-1}\right)$. Converting this data into $\mathrm{mg} \mathrm{DW} \mathrm{m}^{-2} \mathrm{day}^{-1}$ yields a range of 6,223$7,062 \mathrm{mg} \mathrm{DW} \mathrm{m}^{-2} \mathrm{day}^{-1}$ for GPP and 1,929$2,189 \mathrm{mg} \mathrm{DW} \mathrm{m}^{-2}$ day $^{-1}$ for NPP. Compared to these gross and net production rates, the estimated ingestion rate of algal grazing fish $\left(230 \mathrm{mg} \mathrm{DW} \mathrm{m}^{-2}\right.$ day $^{-1}$ ) would be 3.2 and $3.7 \%$ of GPP and between 10.5 and $11.9 \%$ of NPP. If the lower bounds of the $95 \%$ confidence intervals are substituted for the model predictions, the estimated ingestion rate of algal grazing fish increases to $11.7-15.3 \%$ of NPP.

The second approach to estimate the loss of algal biomass to grazing was to estimate chlorophyll concentrations from Secchi depths as above, then convert this data into $\mathrm{mg} \mathrm{DW}$ using conservative 


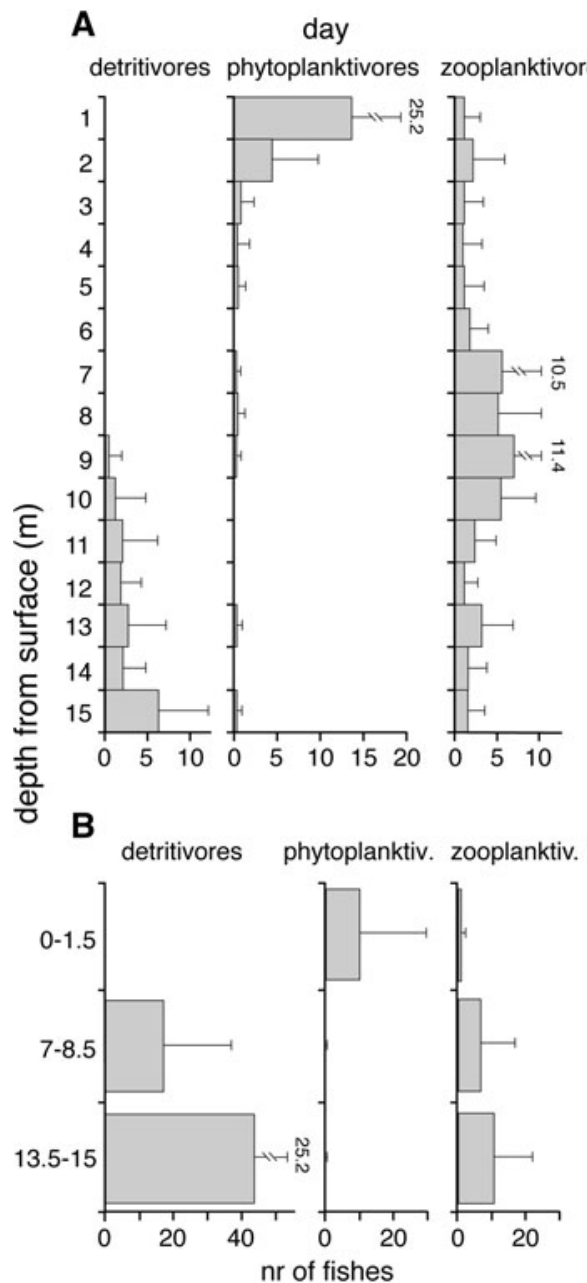

Fig. 3 Mean catch rates and one standard deviation in gill nets during 8 days and 8 nights between August 1981 and July 1982 . Mean number of fishes at each depth, are given per $10 \mathrm{~m}^{2}$ in A vertical gill nets covering the whole column and $\mathbf{B}$ horizontal

estimates of the carbon to chlorophyll ratio of phytoplankton and carbon to DW ratio. Using the lowest measured $\mathrm{C}$ : Chl ratio in Lake Victoria of $72 \mathrm{mg} \mathrm{C} / \mathrm{mg} \mathrm{Chl} \mathrm{(Guildford} \mathrm{et} \mathrm{al.,} \mathrm{2003)} \mathrm{and} \mathrm{the} \mathrm{factor}$ of 2 for $\mathrm{C}$ to DW biomass, then the phytoplankton DW concentration at the study site varied between 994 and $4,413 \mathrm{mg} \mathrm{DW} \mathrm{m}^{-3}$. At the station near Nyamatala Island $(8 \mathrm{~m})$ there was no evident vertical stratification of the water column parameters so we can estimate the algal standing crop as varying between 7,952 and $35,305 \mathrm{mg} \mathrm{DW} \mathrm{m}^{-2}$ over the year at that site. If the average ingestion rate of phytoplankton is taken as $230 \mathrm{mg} \mathrm{DW} \mathrm{m}{ }^{-2}$, then this would amount to a loss of $0.7-2.9 \%$ per day of phytoplankton biomass. If the

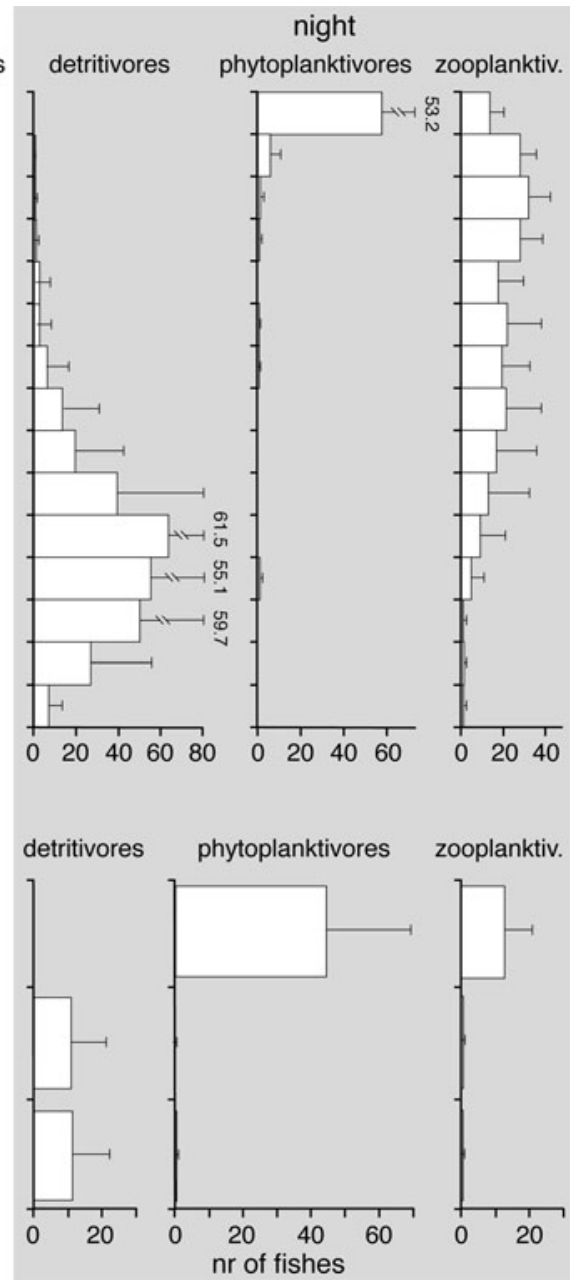

gill nets at three depths in the column. Note that the $y$-axis in B only shows the three depth ranges over which was sampled (i.e. $0-1.5,7-8.5$ and $13.5-15 \mathrm{~m}$ from the surface)

lower bounds of the $95 \%$ confidence intervals are substituted for the model predictions, the estimated ingestion rate of algal grazing fish increases to $0.7-4.1 \%$ per day of phytoplankton biomass.

\section{Discussion}

Sources of error in establishing fish biomass and trophic distribution

The fish biomass in the sublittoral area of the Mwanza Gulf ( $228.5 \mathrm{~kg} \mathrm{ha}^{-1}$ for the demersal and $581 \mathrm{~kg} \mathrm{ha}^{-1}$ for the total ichthyomass) is rather high compared to 
Table 3 Calculation of ingestion rates $(I=(-n 29.6+21.9 B) \times p$, for haplochromines; $I=(n 271+13.3 B) \times p, \quad$ for Oreochromis spp.)

\begin{tabular}{|c|c|c|c|c|c|}
\hline $\begin{array}{l}\text { Troph group } \\
\text { Species }\end{array}$ & $\begin{array}{l}\text { Individual } \\
\text { wt }(\mathrm{g})\end{array}$ & $\begin{array}{l}\text { Biomass } \\
(B)\left(\mathrm{g} \mathrm{m}^{-2}\right)\end{array}$ & $\begin{array}{l}\text { Number of } \\
\text { fish }(n)\left(\mathrm{m}^{-2}\right)\end{array}$ & $\begin{array}{l}\% \text { phyt. } \\
\text { in diet }\end{array}$ & $\begin{array}{l}\text { Ingestion rate } \\
(I)\left(\mathrm{mg} \mathrm{DW} \mathrm{m}^{-2} \mathrm{day}^{-1}\right)\end{array}$ \\
\hline \multicolumn{6}{|l|}{ Phytoplanktivores } \\
\hline H. bwathondii & 5.8 & 9.99 & 1.72 & 90 & 151.0 \\
\hline Oreochromis spp. & 300 & 0.19 & 0.0006 & 90 & 2.4 \\
\hline \multicolumn{6}{|l|}{ Detritivores } \\
\hline Curved head group & 5.8 & 10.97 & 1.89 & 10 & 18.4 \\
\hline H. coprologus & 5.8 & 6.45 & 1.11 & 25 & 27.1 \\
\hline \multicolumn{6}{|l|}{ Zooplanktivores } \\
\hline H. heusinkveldi & 5.6 & 6.38 & 1.14 & 30 & 31.8 \\
\hline Total & & & & & 230.7 \\
\hline
\end{tabular}

From individual fresh weight in grams and biomass in $\mathrm{m}^{-2}(B)$ per species the number of fish $\mathrm{m}^{-2}(n)$ per species was calculated. The ingestion rate was corrected for the proportion $(p)$ of phytoplankton present in the diet of the different taxa

other estimates for Lake Victoria. Kudhongania \& Cordone (1974a) estimated $103 \mathrm{~kg} \mathrm{ha}^{-1}$ for the demersal stocks in Tanzanian waters at the end of the 1960s. The difference is probably caused by the fact that Kudhongania \& Cordone (1974a) also included deep, offshore waters in their calculations. Further, they partly used $38 \mathrm{~mm}$ mesh size cod ends, which are not suitable for catching the relatively small detritivorous and zooplanktivorous haplochromines. However, some assumptions that were made in our and other studies may also have contributed to the differences and in the following paragraphs we discuss their potential impacts.

The assumptions on the gape of the trawl net may strongly influence the biomass estimates. We used a correction factor of 0.33 for the length of the head rope. During a lake-wide bottom trawl survey with MV Ibis (Kudhongania \& Cordone, 1974a, b) the effective fishing width of the most frequently used net, with a head rope of $24 \mathrm{~m}$, was estimated at about $9 \mathrm{~m}$ (Bergstrand \& Cordone, 1971), implying a correction factor of 0.37 . However, it has also been suggested that a correction factor of 0.67 should be used (Gary Kukowski, unpublished report EAFFRO, Mwanza 1978). Using the latter value in our study would imply a reduction of the fish biomass and, consequently, the phytoplankton ingestion rates by fish by a factor of 2 . The maximum height of the net opening of ca. $2 \mathrm{~m}$ is also an assumption. The fact that even in water of $2 \mathrm{~m}$ depth the floats of the net did not reach the surface suggests that a height of $2 \mathrm{~m}$ is not an underestimate. Bergstrand \& Cordone (1971) suggested a gape height $2.3 \mathrm{~m}$ for the nets of MV Ibis, which does not differ much from our estimate.
Our assumption that $2 / 3$ of the detritivores were caught in bottom trawl nets during the day, may be an overestimation. In the normal gill nets this value approached 2/3 (Fig. 3b), but it should be noted that these nets did not sample the depth range of 8.5-13.5 m. In the vertical net at daytime about half of the detritivores were caught in the bottom $2 \mathrm{~m}$, and about $2 / 3$ in the bottom $3 \mathrm{~m}$ (Fig. 3a). If only half of the detritivores were caught in bottom trawls by day, the total amount of detritivores and phytoplanktivores and consequently their ingestion rates would increase by about $33 \%$.

We also used a relatively high speed for MV Mdiria. Most studies used a speed of 2.5-3 nautical miles $\mathrm{h}^{-1}$ for similar sized trawlers (Bergstrand \& Cordone, 1971; Muller \& Benda, 1981; Goudswaard et al., 1995). Gary Kukowski (unpublished) estimated the speed of MV Mdiria at 3.5 nautical miles $\mathrm{h}^{-1}$, which we used here. Using a speed of 3 miles would increase the catches, and consequently the amount of phytoplanktivorous fish, by $14 \%$.

Compared to trawl nets, gill nets are inefficient and generally size and species selective. Detritivores are probably swimming smaller distances than zooplanktivores, and may thus have lower encounter rates with gill nets, though this may be balanced by the fact that zooplanktivores are somewhat more slender and consequently have a greater chance to pass through the smallest $(2.5 \mathrm{~cm})$ mesh. We also did not sample crepuscular hours, when many fish are active, hence reducing the number of fish caught with gill nets. However, gill net catches were only used to establish 
the relative distribution of the trophic groups in the water column. Finally, bottom and surface trawl catches concomitantly with gill netting supported the distribution patterns observed in the latter.

Sources of error in establishing phytoplankton consumption by fish

Moriarty et al. (1973) remarked that the equation for the ingestion rate of phytoplankton in $H$. nigripinnis was only an approximate guide because insufficient data were available for one of the parameters on the rate of stomach emptying. Further, the mean size of the Oreochromis species in Lake Victoria was larger than the size range for which Moriarty et al. (1973) established the equation, which may underestimate their ingestion rate.

Irrespective of these uncertainties, the original grazing rate of phytoplankton by fish in the Mwanza Gulf was likely to be higher than calculated because: (1) many species allocated to other trophic groups included some phytoplankton in their diet (e.g. Witte \& van Oijen, 1990); (2) at the end of the 1960s the Oreochromis densities (Kudhongania \& Cordone, 1974b), and thus their grazing rates, in the Mwanza Gulf were approximately ten times higher than in 1978/1979 (thus resulting in ca. $25 \mathrm{mg} \mathrm{DW} \mathrm{m}^{-2}$ ). Correcting for all possible underestimations mentioned above might result in a total phytoplankton ingestion rate by fish that is about 1.5 times higher than calculated in Table 3, which would amount to ca. $350 \mathrm{mg} \mathrm{DW} \mathrm{m}{ }^{-2}$ day $^{-1}$.

Sources of error in establishing phytoplankton production

In the absence of reliable direct measurements of phytoplankton production and biomass at our study site in Lake Victoria, we have used empirical relationships to estimate both parameters from Secchi depth measurements. The relationship between chlorophyll concentration and Secchi depth includes both historical and modern day measurements from the entire lake and demonstrates that phytoplankton biomass is the dominant factor controlling the optical properties of Lake Victoria (Silsbe et al., 2006). Our estimated range of chlorophyll values from measured Secchi depths assumes this empirical relationship is strictly adhered to, though certainly deviations from this relationship are probable. We have therefore also used the $95 \%$ confidence intervals about this relationship to demonstrate the potential impact of grazing on phytoplankton production and biomass. When converting chlorophyll concentrations to dry phytoplankton weight, we have used the smallest reported carbon to chlorophyll ratio measured in the African Great Lakes (Guildford et al., 2003) while our assumed ratio of DW to carbon of 2 is the mean value of a relatively constrained range (1.8 to 2.2; Strickland, 1965). We therefore have purposefully taken the lowest possible estimate of phytoplankton DW to present the maximum probable impact of daily phytoplankton grazing. Our estimation of NPP also follows this same principle, our assumed photosynthetic quotient of 1.2 is at the lowest end of possible values while our assumption that $31 \%$ of GPP is retained after respiration is lower than the few unpublished measurements performed in Mwanza Gulf by Olsen. Consequently we have likely underestimated net primary production in order to present the maximum probable impact of daily phytoplankton grazing.

The impact of changes in grazing pressure

In contrast to most other studies dealing with composition and standing stocks of fish taxa in Lake Victoria (e.g. Kudhongania \& Cordone, 1974a, b; Benda, 1981; Muller \& Benda, 1981; Witte, 1981; Goudswaard et al., 2008; Okaronon, 1994; but see Goldschmidt et al., 1993), we considered the fish in the entire column. This resulted in 2.6 times higher biomass per square metre and a remarkably high contribution of phytoplanktivorous haplochromines before the ecological changes in the Mwanza Gulf. Nevertheless, fish only consumed 3 and $12 \%$ of daily gross and NPP, respectively.

In Lake George the total daily intake of phytoplankton has been estimated at $34 \mathrm{mg} \mathrm{C} \mathrm{m}^{-2}(=68 \mathrm{mg}$ DW m$\left.{ }^{-2}\right)$ for fish and $504 \mathrm{mg} \mathrm{C} \mathrm{m}^{-2}(=1,008 \mathrm{mg}$ DW $\mathrm{m}^{-2}$ ) for zooplankton (Moriarty et al., 1973). Phytoplankton standing crops were on the order of $600 \mathrm{mg} \mathrm{Chl} \mathrm{m}^{-2}$ in shallow Lake George (Ganf, 1974) or $86,400 \mathrm{mg} \mathrm{DW} \mathrm{m}^{-2}$ using our conversion factors (72 $\mathrm{mg} \mathrm{C} / \mathrm{mg} \mathrm{Chl} \times 2 \mathrm{mg} \mathrm{DW} / \mathrm{mg} \mathrm{C}$ ); so losses to fish or zooplankton grazing were a very minor control on the abundance of algae in that hypereutrophic ecosystem dominated by cyanobacteria.

By the end of the 1980s, the only phytoplankton feeding fish in our study area was $O$. niloticus. The 
mean catch rate in the bottom trawls was $0.8 \mathrm{~kg} \mathrm{~h}^{-1}$ (Ligtvoet et al., 1995), which equals to $0.15 \mathrm{~kg} \mathrm{ha}^{-1}$ and to a phytoplankton intake of only $0.2 \mathrm{mg}$ $\mathrm{DW} \mathrm{m}^{-2}$ day $^{-1}$. In this calculation the proportion of phytoplankton in the diet of $O$. niloticus was kept at $90 \%$. However, studies in the northern part of the lake showed a strong reduction in the proportion of phytoplankton contributing to the diet of $O$. niloticus (Gophen et al., 1993; Njiru et al., 2004; Bwanika et al., 2006). From 1992 onwards some detritivorous haplochromines started to recover in the Mwanza Gulf, but by 2005 their biomass at the studied stations was still less than $20 \%$ of that in the 1970s (Witte et al. 2007a). Moreover, they did not include phytoplankton in their diet anymore (Kishe-Machumu et al., 2008). Finally, of the specialized phytoplanktivore $H$. bwathondii only rarely an individual was encountered since the late 1980s. Consequently the current grazing of phytoplankton by tilapiine and haplochromine cichlids seems negligible.

In the old ecosystem of the Mwanza Gulf, algal grazing fish consumed only between 3 and $12 \%$ of daily gross and NPP, respectively. Even if we would multiply this with a factor of 1.5 because of uncertainties and underestimates mentioned in the "Sources of error in establishing fish biomass and trophic distribution" section, the loss by grazing would still be not more than $18 \%$ of the daily net production. Obviously these loss rates would not be adequate by themselves to control the phytoplankton population that occurred then, and losses to zooplankton grazing, sedimentation or cell death would most likely have been much more important. Conversely, the loss of the low grazing pressure that we estimated for the pre-Nile perch period would not account for the dramatic increase in algal abundance and primary productivity that was measured by the 1990s (Mugidde, 1993).

It is possible that if all the fish grazing were highly selective of a single relatively minor phytoplankton species then control on that phytoplankton species might be accomplished by fish grazing. Given the phytoplankton composition based on counts recorded by Akiyama et al. (1977), diatoms especially and the cyanobacteria Anabaena were numerically dominant at the time of chlorophyll maxima and so were not likely to be under fish grazing control. Aulacoseira [then Melosira] "was the most dominant genus in the water" and "occupied 40-90\% of the phytoplankton in the stomachs of Tilapia esculenta [now
Oreochromis esculentus] caught in Mwanza Gulf and the Southern area of the lake" (quotes from Akiyama et al., 1977). Given this observation it seems unlikely that at least the Oreochromis spp. were selectively grazing, but we cannot rule out that the haplochromines were selectively grazing.

The recent changes in the fish community of Lake Victoria may have had an impact on the zooplankton community and thus on their grazing rates on phytoplankton. However, the decline of the zooplanktivorous haplochromines in the 1980s (Witte et al., 1992, 2007b), though partly compensated by an increase in the population of the cyprinid $R$. argentea (Wanink, 1999; Wanink et al., 2002), would rather have increased the zooplankton community and thus cannot explain the phytoplankton blooms at the end of the 1980s. Furthermore, experimental manipulation of crustacean abundance in 1992 in the northern part of the lake failed to produce any detectable effects of grazing by zooplankton (Lehman \& Branstrator, 1993). Nevertheless, we cannot exclude an effect by zooplankton earlier in time. A shift from large herbivorous zooplankton, to small-bodied predatory cyclopoids started already in the 1960s, before the changes in the fish community (Wanink et al., 2002) and may have had an impact on the phytoplankton community. However, Wanink et al. (2002) suggested a reversed scenario in which eutrophication caused a shift in predominance from diatoms to cyanobacteria, resulting in a shift in zooplankton composition. Since the introduction of the Nile perch, the Lake Victoria basin is amongst the fastest growing populated regions in the world. Therefore, it is likely that anthropogenic induced mobilization of nutrients into Lake Victoria has been and continues to be the dominant mechanism driving algal biomass (Hecky et al., 2010).

To conclude we want to note that, while eutrophication increased, grazing rates of both fish and zooplankton, which were already low, seemed to have decreased since the 1980s. Unless other organisms make use of the phytoplankton in Lake Victoria, the current fate of a major part of algal production must be to contribute to detritus. It is unknown if the strongly increased abundance of invertebrate detritivores, particularly the shrimp Caridina nilotica (Roux) (Goldschmidt et al., 1993; Goudswaard et al., 2006; Budeba \& Cowx, 2007) could compensate for an increased detritus production. If not, decomposition of excessive amounts of detritus in deep water or in the surface 
sediments might contribute to enhanced and prolonged hypoxia in Lake Victoria.

Acknowledgments We thank the staff of the Tanzania Fishery Research Institute and of the Freshwater Fisheries Training Institute Nyegezi for their help. The crew of MV Mdiria, Mohja Kayeba and the late Aloys Peter are thanked for their skilful fishing. We are indebted to Martin Brittijn for drawing two of the figures and to Kees Barel, Jacco van Rijssel and three anonymous reviewers for comments on earlier drafts of this paper. Financial support was obtained from WOTRO (grants W87-129, W87-189, W84-488 and WB84-587), the section DPO of the Netherlands Ministry of Foreign Affairs, Stichting Leids Universiteits-Fonds, Schure-Beijerinck Popping Fonds and the van Tienhoven Stichting.

Open Access This article is distributed under the terms of the Creative Commons Attribution Noncommercial License which permits any noncommercial use, distribution, and reproduction in any medium, provided the original author(s) and source are credited.

\section{References}

Akiyama, T., A. A. Kajumulo \& S. Olsen, 1977. Seasonal variations of plankton and physicochemical conditions in Mwanza Gulf, Lake Victoria, East Africa. Bulletin of Freshwater Fisheries Research Laboratory 27: 49-61.

Benda, R. S., 1981. A comparison of bottom trawl catch rates in the Kenya waters of Lake Victoria. Journal of Fish Biology 18: 609-613.

Bergstrand, E. \& A. J. Cordone, 1971. Exploratory bottom trawling in Lake Victoria. African Journal of Tropical Hydrobiology and Fisheries 1: 13-23.

Budeba, Y. L. \& I. G. Cowx, 2007. Contribution of Caridina nilotica (Roux) in the dagaa fishery in Lake Victoria, Tanzania. Aquatic Ecosystem Health and Management 10: 381-391.

Bwanika, G. N., L. J. Chapman, Y. Kizito \& J. Balirwa, 2006. Cascading effects of introduced Nile perch (Lates niloticus) on the foraging ecology of Nile tilapia (Oreochromis niloticus). Ecology of Freshwater Fish 15: 470-481.

Corbet, P. S., 1961. The food of non-cichlid fishes in the Lake Victoria basin, with remarks on their evolution and adaptation to lacustrine conditions. Proceedings of the Zoological Society of London 136: 1-101.

De Zeeuw, M. P., M. Mietes, P. Niemantsverdriet, S. Ter Huurne \& F. Witte, 2010. Seven new species of detritivorous and phytoplanktivorous haplochromines from Lake Victoria. Zoologische Mededelingen 84: 201-250.

Ganf, G. G., 1974. Incident solar irradiance and underwater light penetration as factors controlling the chlorophyll $a$ content of a shallow equatorial lake (Lake George, Uganda). Journal of Ecology 62: 593-609.

Goldschmidt, T., F. Witte \& J. de Visser, 1990. Ecological segregation of zooplanktivorous haplochromines (Pisces: Cichlidae) from Lake Victoria. Oikos 58: 343-355.
Goldschmidt, T., F. Witte \& J. Wanink, 1993. Cascading effects of the introduced Nile perch on the detritivorous/phytoplanktivorous species in the sublittoral areas of Lake Victoria. Conservation Biology 7: 686-700.

Gophen, M., P. B. O. Ochumba, U. Pollinger \& L. S. Kaufman, 1993. Some aspects of perturbation in the structure and biodiversity of the ecosystem of Lake Victoria (East Africa). Verhandlungen der Internationalen vereinigung für Theoretische und Angewandte Limnologie 25: 856-859.

Goudswaard, P. C., P. J. Mous, W. Ligtvoet \& W. L. T. van Densen, 1995. Gears and boats. In Witte, F. \& W. L. T. van Densen (eds), Fish Stocks and Fisheries of Lake Victoria. Samara Publishing, Cardigan, UK: 83-117.

Goudswaard, P. C., F. Witte \& E. F. B. Katunzi, 2002. The tilapiine fish stock of Lake Victoria before and after the Nile perch upsurge. Journal of Fish Biology 60: 838-856.

Goudswaard, P. C., F. Witte \& J. H. Wanink, 2006. The shrimp Caridina nilotica in Lake Victoria (East Africa), before and after the Nile perch increase. Hydrobiologia 563: $31-44$.

Goudswaard, K. ( P. C.)., F. Witte \& E. F. B. Katunzi, 2008. The invasion of an introduced predator, Nile perch (Lates niloticus, L.) in Lake Victoria (East Africa): chronology and causes. Environmental Biology of Fishes 81: 127-139.

Guildford, S. J., R. E. Hecky, W. D. Taylor, R. Mugidde \& H. A. Bootsma, 2003. Nutrient enrichment experiments in tropical great lakes Malawi/Nyasa and Victoria. Journal of Great Lakes Research 29(Supplement 2): 89-106.

Hecky, R. E., 1993. The eutrophication of Lake Victoria. Verhandlungen der Internationalen Vereinigung für Theoretische und Angewandte Limnologie 25: 39-48.

Hecky, R. E. \& F. W. B. Bugenyi, 1992. Hydrology and chemistry of the African Great Lakes and water quality issues: problems and solutions. Mitteilungen der Internationalen Vereinigung für Theoretische und Angewandte Limnologie 23: 45-54.

Hecky, R. E., F. W. B. Bugenyi, P. Ochumba, J. F. Talling, R. Mugidde, M. Gophen \& L. Kaufman, 1994. Deoxygenation of the deep water of Lake Victoria, East Africa. Limnology and Oceanography 39: 1476-1481.

Hecky, R. E., R. Mugidde, P. S. Ramlal, M. R. Talbot \& G. W. Kling, 2010. Multiple stressors cause rapid ecosystem change in Lake Victoria. Freshwater Biology 55(Suppl. 1): $19-42$.

Hoogerhoud, R. J. C. \& F. Witte, 1981. Revision of species from the "Haplochromis" empodisma group. Netherlands Journal of Zoology 31: 232-274.

Kilham, S. S. \& P. Kilham, 1990. Tropical limnology: do African lakes violate the "first law" of limnology. Verhandlungen der Internationalen Vereinigung für Theoretische und Angewandte Limnologie 24: 68-72.

Kishe-Machumu, M., F. Witte \& J. H. Wanink, 2008. Dietary shift in benthivorous cichlids after the ecological changes in Lake Victoria. Animal Biology 58: 401-417.

Kolding, J., P. van Zwieten, O. Mkumbo, G. Silsbe \& R. E. Hecky, 2008. Are the Lake Victoria fisheries threatened by exploitation or eutrophication? Towards an ecosystem based approach to management. In Bianchi, G. \& H. R. Skjodal (eds), The Ecosystem Approach to Fisheries. CAB International, Wallingford: 309-354. 
Kudhongania, A. W. \& A. J. Cordone, 1974a. Batho-spatial distribution patterns and biomass estimates of the major demersal fishes in Lake Victoria. The African Journal of Tropical Hydrobiology and Fisheries 3: 15-31.

Kudhongania, A. W. \& A. J. Cordone, 1974b. Past trends, present stocks and possible future state of the fisheries of the Tanzania part of the Lake Victoria. The African Journal of Tropical Hydrobiology and Fisheries 3: 167-181.

Lehman, J. T. \& D. K. Branstrator, 1993. Effects of nutrients and grazing on the phytoplankton of Lake Victoria. Verhandlungen der Internationalen Vereinigung für Theoretische und Angewandte Limnologie 25: 850-855.

Ligtvoet, W., P. J. Mous, O. C. Mkumbo, Y. L. Budeba, P. C. Goudswaard, E. F. B. Katunzi, M. M. Temu, J. H. Wanink \& F. Witte, 1995. The Lake Victoria fish stocks and fisheries. In Witte, F. \& W. L. T. van Densen (eds), Fish Stocks and Fisheries of Lake Victoria: A Handbook for Field Observations. Samara Publishing Limited, Cardigan: 12-53.

Lowe-McConnell, R. H., 1956. Observations on the biology of Tilapia (Pisces-Cichlidae) in Lake Victoria, East Africa. East African Fisheries Research Organization Supplement Publication 1: 1-72.

Lung'ayia, H., L. Sitoki \& M. Kenyanya, 2001. The nutrient enrichment of Lake Victoria (Kenyan waters). Hydrobiologia 458: 75-82.

Moriarty, D. J. W., J. P. E. C. Darlington, I. G. Dunn, C. M. M. Moriarty \& M. P. Tevlin, 1973. Feeding and grazing in Lake George, Uganda. Proceedings of the Royal Society London 184: 299-319.

Mugidde, R., 1993. The increase in phytoplankton primary productivity and biomass in Lake Victoria. Verhandlungen der Internationalen Vereinigung für Theoretische und Angewandte Limnologie 25: 846-849.

Muller, R. \& R. S. Benda, 1981. Comparison of bottom trawl stock densities in the inner Kavirondo Gulf of Lake Victoria. Journal of Fish Biology 19: 399-401.

Njiru, M., J. B. Okeyo-Owuor, M. Muchiri \& I. G. Cowx, 2004. Shifts in the food of Nile tilapia, Oreochromis niloticus (L.) in Lake Victoria, Kenya. African Journal of Ecology 42: 163-170.

Ochumba, P. B. O., 1995. Limnological changes in Lake Victoria since the Nile perch introduction. In Pitcher, T. J. \& P. J. B. Hart (eds), The Impact of Species Changes in African Lakes. Chapman and Hall, London: 33-43.

Ochumba, P. B. O. \& D. I. Kibaara, 1989. Observations on the blue-green algal blooms in open waters of Lake Victoria, Kenya. African Journal of Ecology 27: 23-34.

Ogutu-Ohwayo, R. \& R. E. Hecky, 1991. Fish introductions in Africa and some of their implications. Canadian Journal of Fisheries and Aquatic Sciences 48(Suppl. 1): 8-12.

Okaronon, J. O., 1994. Current composition, distribution and relative abundance of the fish stocks of Lake Victoria, Uganda. The African Journal of Tropical Hydrobiology and Fisheries 5: 89-100.

Scheren, P. A. G. M., H. A. Zanting \& A. M. C. Lemmens, 2000. Estimation of water pollution sources in Lake Victoria, East Africa: application and elaboration of the rapid assessment methodology. Journal of Environmental Management 58: 235-248.
Silsbe, G.M., 2004. Phytoplankton production in Lake Victoria, East Africa. MSc thesis, University of Waterloo.

Silsbe, G. M., R. E. Hecky \& S. J. Guildford, 2006. Variability of chlorophyll $a$ and photosynthetic parameters in a nutrient-saturated tropical great lake. Limnology and Oceanography 51: 2052-2063.

Strickland, J. D. H., 1965. Production of organic matter in the primary stages of the marine food chain. In Riley, J. P. \& G. Skirrow (eds), Chemical Oceanography, Vol. 1. Academic Press, New York.

Talling, J. F., 1965. The photosynthetic activity of phytoplankton in East African lakes. Internationale Revue der Gesamten Hydrobiologie 50: 1-32.

Trewavas, E., 1983. Tilapiine Fishes of the Genera Sarotherodon, Oreochromis and Danikilia. Trustees of the British Museum (Natural History), London.

Van Oijen, M. J. P., F. Witte \& E. L. M. Witte-Maas, 1981. An introduction to ecological and taxonomic investigations on the haplochromine cichlids from the Mwanza Gulf of Lake Victoria. Netherlands Journal of Zoology 31: 149-174.

Verschuren, D., T. C. Johnson, H. J. Kling, D. N. Edgington, P. R. Leavitt, E. T. Brown, M. R. Talbot \& R. E. Hecky, 2002. History and timing of human impact on Lake Victoria, East Africa. Proceedings of the Royal Society London B 269: 289-294.

Wanink, J. H., 1999. Prospects for the fishery on the small pelagic Rastrineobola argentea in Lake Victoria. Hydrobiologia 407: 183-189.

Wanink, J. H., J. J. Kashindye, P. C. Goudswaard \& F. Witte, 2001. Dwelling at the oxycline: does increased stratification provide a predation refugium for the Lake Victoria sardine Rastrineobola argentea? Freshwater Biology 46: 75-85.

Wanink, J. H., E. F. B. Katunzi, K. P. C. Goudswaard, F. Witte \& W. L. T. van Densen, 2002. The shift to smaller zooplankton in Lake Victoria cannot be attributed to the 'sardine' Rastrineobola argentea (Cyprinidae). Aquatic Living Resources 15: 37-43.

Wanink, J. H., F. Witte, P. C. Goudswaard, E.F. B. Katunzi \& M. Berger, 2005. Changes in biomass and predation pressure of zooplanktivorous fish in the sublittoral waters of the MwanzaGulf of Lake Victoria. In LVFO 2000 Proceedings of Lake Victoria 2000 a New Beginning Conference, 15-19 May 2000, Jinja Uganda: 89-95.

Welcomme, R. L., 1967. Observations on the biology of the introduced species of Tilapia in Lake Victoria. Revue de Zoologie et de Botanique Africaines 76: 249-279.

Witte, F., 1981. Initial results of the ecological survey of the haplochromine cichlid species from the Mwanza Gulf of Lake Victoria (Tanzania): breeding patterns, trophic and species distribution. Netherlands Journal of Zoology 31: 175-202.

Witte, F. \& M. J. P. van Oijen, 1990. Taxonomy, ecology and fishery of haplochromine trophic groups. Zoologische Verhandelingen 262: 1-47.

Witte, F., T. Goldschmidt, J. Wanink, M. van Oijen, K. Goudswaard, E. Witte-Maas \& N. Bouton, 1992. The destruction of an endemic species flock: quantitative data on the decline of the haplochromine cichlids of Lake Victoria. Environmental Biology of Fishes 34: 1-28. 
Witte, F., J. H. Wanink, H. A. Rutjes, H. J. van der Meer \& G. E. E. J. M. van den Thillart, 2005. Eutrophication and its influences on the fish fauna of Lake Victoria. In Vikram Reddy, M. (ed.), Restoration and Management of Tropical Eutrophic Lakes. Science Publishers, Inc., Enfield, NH, USA: $291-328$.

Witte, F., J. H. Wanink \& M. A. Kishe, 2007a. Species distinction and the biodiversity crisis in Lake Victoria.
Transactions of the American Fisheries Society 136: 1146-1159.

Witte, F., J. H. Wanink, M. A. Kishe, O. C. Mkumbo, P. C. Goudswaard \& O. Seehausen, 2007b. Differential decline and recovery of haplochromine trophic groups in the Mwanza Gulf of Lake Victoria. Aquatic Ecosystem Health and Management 10: 416-433. 